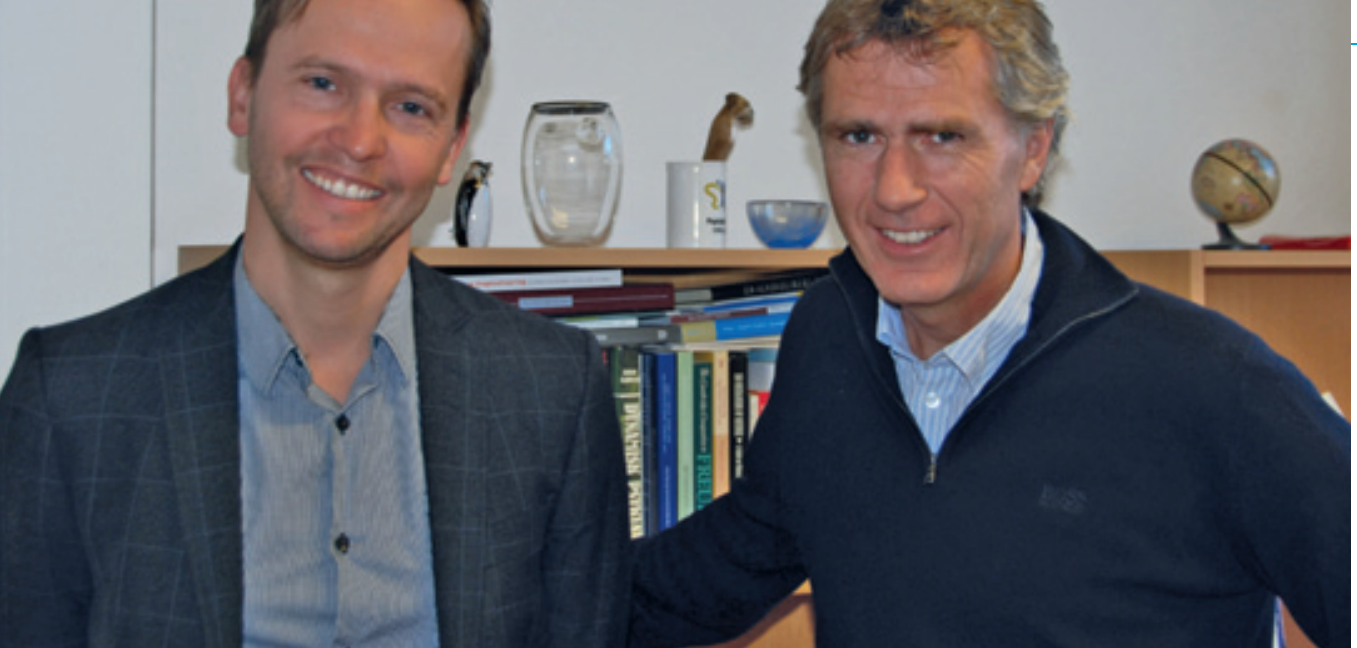

Jon Anders Halvorsen og Lars Lien. Foto Ellen Scheel

\section{Suicidaltanker blant ungdom med akne}

\author{
Ungdom med mye akne har oftere psykososiale vansker enn ungdom \\ med ingen eller lite akne. Suicidaltanker er dobbelt så vanlig.
}

Akne er en vanlig tilstand blant unge. Erfaring tyder på at akne kan påvirke etableringen av sosiale relasjoner og gi lavt selvbilde, men dette er lite undersøkt blant vanlig ungdom. For noen år siden ble det rapportert en mulig sammenheng mellom systemisk behandling med isotretinoin og selvmordstanker.

I en stor tverrsnittsunders $ø$ kelse blant ungdom i Oslo i 2004 ble over 4700 18og 19-åringer bedt om å fylle ut et fire siders spørreskjema (1). $80 \%$ av dem deltok. Spørsmålene var bl.a. knyttet til mental helse, sosiale relasjoner og forekomst av akne. $14 \%$ oppga at de hadde mye eller svært mye akne. Blant dem med svært mye akne var det om lag dobbelt så mange som rapporterte suicidaltanker siste uken sammenliknet med dem ingen eller lite akne (justert for depresjonssymptomer, etnisk bakgrunn og familieinntekt; oddsratio 1,80; 95 \% KI 1,30-2,50). På samme måte var forekomsten av mentale helseproblemer (målt med et validert spørreskjemainstrument; SDQ), lite vennekontakt, mistrivsel på skolen, at man aldri har hatt kjæreste og ikke har debutert seksuelt signifikant assosiert med akne.

Data fra Reseptregisteret viste at svært få av disse ungdommene kan ha blitt behandlet med isotretinoin. Studien tyder derfor på at depresjon og suicidaltanker ved akne snarere skyldes belastningen med å ha en synlig hudsykdom i en sårbar livsfase fremfor å være en bivirkning av aknebehandling.

- Det er viktig å understreke at de fleste med akne ikke har psykiske eller sosiale vansker, sier Jon Anders Halvorsen, som er artikkelens førsteforfatter og klinisk stipendiat i hudsykdommer ved Oslo universitetssykehus, Rikshospitalet. Men noen har det. Det er allmennlegens og hudlegens opp- gave å ta opp slike spørsmål med pasienten. Resultatene setter dessuten spørsmålstegn ved berettigelsen av advarsler om depresjon og suicidaltanker ved bruk av isotretinoin, sier Halvorsen.

Studien inngår i Halvorsens doktorgradsavhandling. Psykiater Lars Lien, også ved Universitetet i Oslo, er hovedveileder. Robert Stern ved Harvard Medical School i Boston, der Halvorsen nylig hadde et forskningsopphold, bidro vesentlig $i$ arbeidet med analysene. I tillegg er Florence Dalgard, Magne Thoresen og Espen Bjertness medforfattere.

\section{Ungdom 2004}

Ungdom 2004 er en populasjonsbasert studie, der de fleste deltakerne også var med i helseundersøkelsen UNGHUBRO i 2000-01. Ungdom 2004 er satt sammen av en serie tverrsnittsstudier og oppfølgingsstudier av ungdom i Oslo og Hedmark. Studien, der man skal kartlegge somatiske og spesielt psykiske problemer hos ungdom, utgår fra Avdeling for allmenn- og samfunnsmedisin ved Universitet i Oslo og er gjennomført i samarbeid med Folkehelseinstituttet og Regionsenter for unge og barns psykiske helse (RBUP Øst og Sør). Prosjektet ledes av Espen Bjertness.

\section{Petter Gjersvik}

petjense@online.no

Tidsskriftet

\section{Litteratur}

1. Halvorsen JA, Stern RS, Dalgard F et al. Suicidal ideation, mental health problems, and social impairment are increased in adolescents with acne: a population-based study. J Invest Dermatol 2010, doi:10.1038/jid.2010.264.

\section{Ordforklaringer}

Suicidaltanker: Deltakerne ble spurt om de den siste uken hadde hatt tanker om å gjøre slutt på livet sitt. Svaralternativene var: ikke plaget, litt plaget, ganske mye plaget, mye plaget. De tre siste alternativene ble betraktet som det å ha hatt suicidaltanker. Spørsmålet er hentet fra det validerte spørreskjemainstrumentet Hopkins Symptom Checklist (HSCL-90), som er et etablert psykometrisk redskap til bruk i epidemiologiske studier.

Mentale helseproblemer: Mentale helseproblemer de siste seks månedene ble rapportert ved bruk av 20 spørsmål fra spørreskjemaet Strengths and Difficulties Questionnaire (SDQ), blant annet hyperaktivitet, emosjonelle vansker, atferdsvansker og vansker med å knytte personlige relasjoner.

Isotretinoin: Isotretinoin er en vitamin Aanalog (retinoid) som hemmer talgkjertelaktivitet og reduserer størrelsen på talgkjertlene. Det hemmer proliferasjonen av sebocytter og gjenoppretter den normale differensieringsprosessen ved akne. Godkjent indikasjon for systemisk behandling er uttalt akne der annen behandling ikke har hatt tilfredsstillende effekt.

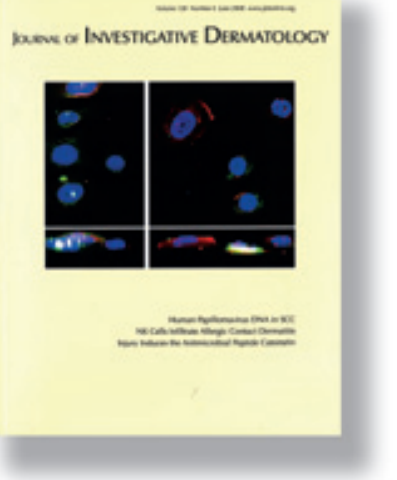

Artikkelen ble e-publisert 16.9. 2010 i tidsskriftet Journal of Investigative Dermatology (www.nature.com/jid) som er det aller høyest rangerte vitenskapelige tidsskriftet innen dermatologi

\section{Tips oss}

Er du iferd med å publisere eller har du nylig publisert eller har du nylig publisert Send tips til erlend.hem@medisin.uio.no www.tidsskriftet.no/ norskforskning 